\title{
Sistem Penunjang Keputusan Pemilihan BumDes Terbaik
}

\author{
Roki Hardianto ${ }^{1}$, Chandra Kusuma ${ }^{2}$, Febrizal Alfarasy Syam $^{3}$ \\ ${ }^{1,3}$ Program Studi Teknik Informatika Fakultas Ilmu Kom| puter Universitas Lancang Kuning \\ ${ }^{2}$ Program Studi Komputerisasi Akuntansi STMIK Dharmapala Riau
}

Jl. Yos Sudarso KM. 8 Rumbai, Pekanbaru, Riau, telp. 08117532015

e-mail: ${ }^{1}$ roki@unilak.ac.id, ${ }^{2}$ chandrakusuma2015.ck23@gmail.com, ${ }^{3}$ febrizal@unilak.ac.id

\begin{abstract}
Abstrak
Pada penelitian ini mengangkat topik tentang sistem penunjang keputusan menggunakan metoda Moora. Multi-Objective Optimization on the basis of Ratio Analysis (MOORA) adalah sistem multi-objektif yang mengoptimalkan dua atau lebih attribut yang saling bertentangan secara bersamaan. Metode ini diterapkan untuk memecahkan masalah dengan perhitungan matematika yang kompleks.Metode MOORA memiliki tingkat fleksibilitas dan kemudahan untuk dipahami dalam memisahkan bagian subjektif dari suatu proses evaluasi kedalam kriteria bobot keputusan dengan beberapa atribut pengambilan keputusan. Metode ini memiliki tingkat selektifitas yang baik karena dapat menentukan tujuan dari kriteria yang bertentangan. Di mana kriteria dapat bernilai menguntungkan (benefit) atau yang tidak menguntungkan (cost). Objek penelitiannya adalah Badan Usaha Milik Desa yang berada di Kabupaten Kampar. Dalam proses penelitian menggunakan sekurang-kurangnya 5 kriteria pengukuran yang akan di proses agar memperoleh keputusan. Pada metode Moora terdapat beberapa langkahlangkah proses yang harus dilakukan, diantaranya adalah sebagai berikut :

1. Menentukan tujuan untuk mengidentifikasi atribut evaluasi yang bersangkutan dan menginputkan nilai kriteria pada suatu alternatif dimana nilai tersebut nantinya akan diproses dan hasilnya akan menjadi sebuah keputusan.

2. Membuat Matriks Keputusan MOORA

3. Matriks Normalisasi Moora

4. Menghitung Nilai Optimasi Multiobjektif MOORA

5. Menentukan Nilai Rangking dari hasil perhitungan MOORA

Hasil output dari penelitian ini bisa menjadi masukkan kepada pemerintah daerah dalam mengambil keputusan. Hasil penelitian ini tentu bisa menjadi motivasi bagi BumDes lain yang tidak masuk dalam peringkat terbaik. Hasil penelitian ini akan lebih kompleks bila menggunakan aspek penilaian yang lebih kompleks.
\end{abstract}

Kata kunci: bumdes, spk, moora, desa, kampar

\begin{abstract}
This research raises the topic of decision support systems using the Moora method. Multi-Objective Optimization on the basis of Ratio Analysis (MOORA) is a multi-objective system that optimizes two or more conflicting attributes simultaneously. This method is applied to solve problems with complex mathematical calculations. The MOORA method has a level of flexibility and ease of understanding in separating the subjective part of an evaluation process into decision weight criteria with several decision-making attributes. This method has a good level of selectivity because it can determine the objectives of conflicting criteria. Where the criteria can be beneficial (benefit) or not profitable (cost). The object of the research is VillageOwned Enterprises in Kampar Regency. In the research process using at least 5 measurement criteria that will be processed in order to obtain a decision. In the Moora method, there are several process steps that must be carried out, including the following:
\end{abstract}


1. Determining the purpose of identifying the relevant evaluation attributes and inputting the criteria value in an alternative where the value will be processed and the result will be a decision.

2. Create a MOORA Decision Matrix

3. Matrix of Normalization Moora

4. Calculating the value of MOORA's multi-objective optimization

5. Determine the Rank Value from the results of the MOORA calculation

The output of this research can be used as input for local governments in making decisions. The results of this study can certainly be a motivation for other BumDes who are not in the best ranking. The results of this study will be more complex when using more complex aspects of the assessment. Convenience of interested parties to be able to find our articles. Keywords: bumdes, spk, moora, village, kampar.

\section{Pendahuluan}

Sistem Penunjang Keputusan (SPK) atau Decision Support System (DSS) adalah Sistem yang interaktif, membantu pengambilan keputusan melalui penggunaan data dan model-model keputusan untuk memecahkan masalah-masalah yang sifatnya semi terstruktur dan tidak terstruktur [1] dan [2]. SPK merupakan sistem berbasis teknologi informasi yang mampu memberikan dan mendukung kemampuan pemecahan masalah maupun kemampuan pengomunikasian untuk masalah semi terstruktur dalam suatu organisasi maupun perusahaan [1], [3] dan [4].

Konsep DSS dimulai akhir tahun 1960 dengan time sharing komputer yaitu untuk pertama kalinya seseorang dapat berinteraksi langsung dengan komputer tanpa harus melalui spesialis informasi. Istilah DSS diciptakan pada tahun 1971 oleh Anthony Gory dan Scott Morton untuk mengarahkan aplikasi komputer pada pengambilan keputusan manajemen. Konsep DSS menggunakan informasi spesifik yang ditujukan untuk membantu manajemen dalam mengambil keputusan dengan menggunakan model sebagai dasar pengembangn alternatif yang secara interaktif dapat digunakan oleh pemakai. Dari penjelasan tersebut maka dapat diketahui bahwa DSS mempunyai karakteristik tersendiri, antara lain :

1. DSS dirancang untuk membantu pengambil keputusan dalam memecahkan masalah yang bersifat semi terstruktur ataupun tidak terstruktur,

2. Dalam proses pengolahannya, DSS mengkombinasikan penggunaan modelmodel/teknik-teknik analisis dengan teknik pemasukan data konvensional serta fungsifungsi pencari/interogasi informasi,

3. DSS dirancang sedemikian rupa, sehingga dapat digunakan dengan mudah oleh orang yang tidak memiliki dasar kemampuan pengoperasian komputer yang tinggi,

4. DSS dirancang dengan menekankan pada aspek fleksibilitas serta kemampuan adaptasi yang tinggi, sehingga mudah disesuaikan dengan kebutuhan pemakai.

Pada penelitian ini berjudul "Sistem Penunjang Keputusan Pemilihan BumDes Terbaik", berfokus kepada penentuan Badan Usaha Milik Desa (BumDes) di Kabupaten Kampar. Kabupaten Kampar adalah salah satu kabupaten di Provinsi Riau yang berbatasan langsung dengan Provinsi Sumatera Barat, ibukotanya adalah Bangkinang. Perekonomian di Kabupaten Kampar adalah perkebunan, pertanian, perikanan. Perkebunan yang dominan adalah sawit dan karet sedangkan pertanian adalah sawah tetapi relatif tidak dominan dibandingkan perkebunan sawit dan karet.

Berdasarkan Peraturan Menteri Desa, Pembangunan Daerah Tertinggal dan Transmigrasi No.4 Tahun 2015 tentang Pendirian, Pengurusan dan Pengelolaan dan Pembubaran Badan Usaha Milik Desa menerangkan bahwa Badan Usaha Milik Desa dapat berbentuk Perseroan ataupun Lembaga Keuangan Mikro yang bertujuan untuk kesejahteraan desa, sebagaimana dalam Pasal 8 Peraturan Menteri ini tentang Bumdes. 
Proses penelitian ini sudah berjalan dengan pada tahapan pembuatan aplikasi Sistem Penunjang Keputusan berbasis web. Dinas Desa di Kabupaten Kampar dapat terbantu dengan output penelitian ini dalam hal penentuan BumDes terbaik. Sekarang sedang dalam proses pengujian sistem dan melakukan sinkronisasi perhitungan matematika metode moora terhadap objek Badan Usaha Milik Desa (BumDes) di Kabupaten Kampar. Dalam pengumpulan data dilaksanakan dalam tahapan mengumpulkan data BumDes.

Proses penelitian ini sudah berjalan dengan pada tahapan pembuatan aplikasi Sistem Penunjang Keputusan berbasis web. Dinas Desa di Kabupaten Kampar dapat terbantu dengan output penelitian ini dalam hal penentuan BumDes terbaik. Sekarang sedang dalam proses pengujian sistem dan melakukan sinkronisasi perhitungan matematika metode moora terhadap objek Badan Usaha Milik Desa (BumDes) di Kabupaten Kampar. Dalam pengumpulan data dilaksanakan dalam tahapan mengumpulkan data BumDes.

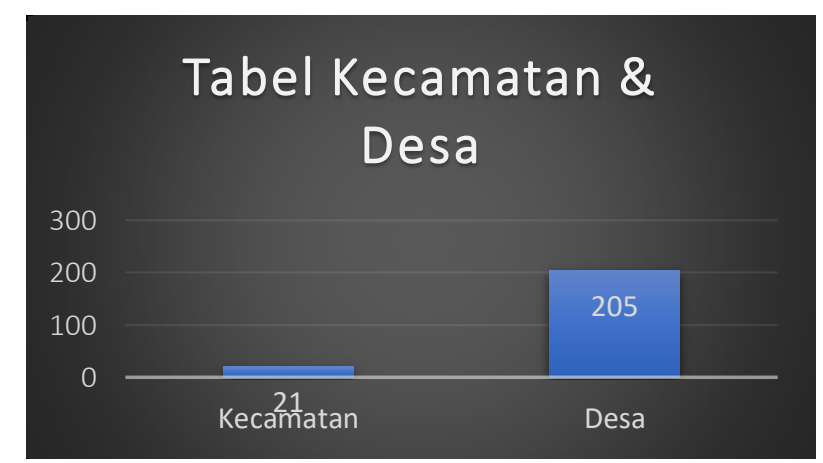

Gambar 1. Jumlah Kecamatan dan Desa Kab. Kampar

Pada tabel terlihat adalah jumlah kecamatan dan desa yang ada di Kabupaten Kampar. Terdapat 21 kecamatan dan 205 desa. Pada data kementerian desa menyatakan bahwa setiap desa terdapat satu BumDes yang dikelola oleh oleh pemerintah desa [5] , [6].

Peneliti sekarang sedang melakukan pengolahan data penilaian akan BumDes berdasarkan atribut-atribut penilaian yang pernah dilakukan oleh pemerintah Kabupaten Kampar. Karena dalam metode Moora atribut tersebutkan akan dikonversikan kepada nilai bobot dalam matematis. [7], [8], [5]

Sistem Penunjang Keputusan yang diterapkan dalam penelitian ini adalah metode MultiObjective Optimization on the basis of Ratio Analysis (MOORA) yaitu metode sistem penunjang keputusan menggunakan perkalian sebagai untuk menghubungkan rating atribut,dimana rating atribut harus dipangkatkan dulu dengan bobot yang bersangkutan, Preferensi untuk alternatif Si menurut Mesran dan kawan-kawan pada jurnalnya [9], [2], [10].

\section{Metode Penelitian}

Metode yang digunakan pada penelitian ini adalah Multi-Objective Optimization on the basis of Ratio Analysis (MOORA). Yang dilakukan penilaian adalah Badan Usaha Milik Desa di Kabupaten Kampar. Langkah-langkah penyelesaian masalah menggunakan Sistem Penunjang Keputusan metode MOORA, antara lain

a. Membuat matriks keputusan 
$\boldsymbol{X}=\left[\begin{array}{ccccc}x_{11} & \ldots & x_{1 i} & \ldots & x_{1 n} \\ \vdots & . & \vdots & & \vdots \\ \vdots & . & \ddots & . & \vdots \\ x_{j 1} & \ldots & x_{i j} & \ldots & x_{j n} \\ \vdots & . & \vdots & \ddots & \vdots \\ x_{m 1} & \ldots & x_{m i}^{*} & \ldots & x_{m n}\end{array}\right]$

\section{Keterangan}

- $\mathbf{x}_{\mathrm{ij}}$ : Respon alternatif $\mathrm{j}$ pada kriteria $\mathrm{i}$

- $\mathbf{i}: 1,2,3, \ldots, \mathbf{n}$ adalah nomor urutan atribut atau kriteria

- $\mathbf{j}: 1,2,3, \ldots, \mathrm{m}$ adalah nomor urutan alternatif

- X: Matriks Keputusan

b. Melakukan normalisasi terhadap matrik $\mathrm{x}$

$$
X_{i j}^{*}=\frac{x_{i j}}{\sqrt{\left[\sum_{\mathrm{j}=1}^{\mathrm{m}} x_{\mathrm{ij}}^{2}\right]}}
$$

\section{Keterangan}

- $\mathbf{x}_{\mathrm{ij}}$ : Matriks alternatif $\mathrm{j}$ pada kriteria $i$

- $\mathbf{i}: 1,2,3, \ldots, \mathbf{n}$ adalah nomor urutan atribut atau kriteria

- $\mathbf{j}: 1,2,3, \ldots, \mathrm{m}$ adalah nomor urutan alternatif

- $\mathbf{X}_{\mathrm{ij}}^{*}$ : Matriks Normalisasi alternatif j pada kriteria $i$

c. Menentukan matriks normalisasi terbobot

$$
\mathrm{W}_{\mathrm{j}}{ }^{*} \mathrm{X}_{\mathrm{ij}}
$$

d. Menentukan Hasil Preferensi

$$
\mathrm{Yi}=\sum_{j=1}^{g} w j X * i j-\sum_{j=g+1}^{n} w j X i j
$$

Kriteria Moora

1. Pengurus maksudnya adalah kelengkapan susunan organisasi Badan Usaha Milik Desa

2. Jumlah Usaha adalah banyak usaha yang dilaksanakan oleh Badan Usaha Milik Desa

3. Lama Usaha maksudnya lama waktu usaha yang digeluti oleh Badan Usaha Milik Desa

4. Prestasi adalah prestasi yang didapat selama Badan Usaha Milik Desa berdiri dengan pelaksanaan usaha

5. Keuntungan adalah besar persentase keuntungan yang diperoleh oleh Badan Usaha Milik Desa

\section{Hasil dan Pembahasan} (BumDes)

Alternatif yang digunakan pada metode Moora ini adalah 21 Badan Usaha Milik Desa

\begin{tabular}{|c|l|c|}
\hline No & Alternatif & $\begin{array}{l}\text { Kode } \\
\text { Alternatif }\end{array}$ \\
\hline 1 & BumDes Tanjung Alai & A1 \\
\hline 2 & BumDes Rumbio & A2 \\
\hline 3 & BumDes Koto Mesjid & A3 \\
\hline
\end{tabular}




\begin{tabular}{|c|l|c|}
\hline 4 & $\begin{array}{l}\text { BumDes Mitra Usaha } \\
\text { Teratai }\end{array}$ & A4 \\
\hline 5 & BumDes Suka Maju & A5 \\
\hline 6 & BumDes Danau Sontul & A6 \\
\hline 7 & BumDes Sungai Pagar & A7 \\
\hline 8 & BumDes Mayang Pongkai & A8 \\
\hline 9 & $\begin{array}{l}\text { BumDes Kampung Panjang } \\
\text { Air Tiris }\end{array}$ & A9 \\
\hline 10 & BumDes Laboy Jaya & A10 \\
\hline 11 & BumDes Rindan Permai & A11 \\
\hline 12 & BumDes Merangin & A12 \\
\hline 13 & BumDes Salo & A13 \\
\hline 14 & BumDes Pantai Raja & A14 \\
\hline 15 & BumDes Kuala Nenas & A15 \\
\hline 16 & BumDes Teratak & A16 \\
\hline 17 & BumDes Gunung Sahilan & A17 \\
\hline 18 & BumDes Pulau Birandang & A18 \\
\hline 19 & BumDes Teratak Buluh & A19 \\
\hline 20 & BumDes Gunung Malelo & A20 \\
\hline 21 & BumDes Koto Perambahan & A21 \\
\hline
\end{tabular}

Berikut ini adalah kriteria yang digunakan dalam proses metode Moora

\begin{tabular}{|l|l|l|l|}
\hline Krteria & Keterangan & Jenis & Bobot \\
\hline C1 & Pengurus & Benefit & 0.25 \\
\hline C2 & Jumlah Usaha & Benefit & 0.20 \\
\hline C3 & Lama Usaha & Benefit & 0.20 \\
\hline C4 & Prestasi & Cost & 0.15 \\
\hline C5 & Keuntungan & Cost & 0.20 \\
\hline
\end{tabular}

Dibawah ini adalah tabel jenis-jenis kriteria $\mathrm{C} 1$ pada proses metode moora

\begin{tabular}{|l|l|l|}
\hline Range C1 & Keterangan & Bobot \\
\hline Tidak Lengkap & Buruk & 0.5 \\
\hline Lengkap & Baik & 1.0 \\
\hline
\end{tabular}

Dibawah ini adalah tabel jenis-jenis kriteria $\mathrm{C} 2$ pada proses metode moora

\begin{tabular}{|l|l|l|}
\hline Range C2 & Keterangan & Bobot \\
\hline 1 Usaha & Cukup Baik & 0.25 \\
\hline 2 Usaha & Baik & 0.5 \\
\hline$>$ 3 Usaha & Sangat Baik & 1.0 \\
\hline
\end{tabular}

Dibawah ini adalah tabel jenis-jenis kriteria C3 pada proses metode moora

\begin{tabular}{|l|l|l|}
\hline Range C3 & Keterangan & Bobot \\
\hline$<1$ Tahun & Cukup Baik & 0.25 \\
\hline 2 Tahun & Baik & 0.5 \\
\hline$>$ 3 Tahun & Sangat Baik & 1.0 \\
\hline
\end{tabular}

Dibawah ini adalah tabel jenis-jenis kriteria $\mathrm{C} 4$ pada proses metode moora 


\begin{tabular}{|l|l|l|}
\hline Range C4 & Keterangan & Bobot \\
\hline Tidak Ada & Buruk & 0.25 \\
\hline Ada 1 Prestasi & Baik & 0.5 \\
\hline Ada $>$ 1 Prestasi & Sangat Baik & 1.0 \\
\hline
\end{tabular}

Dibawah ini adalah tabel jenis-jenis kriteria C5 pada proses metode moora

\begin{tabular}{|l|l|l|}
\hline Range C5 & Keterangan & Bobot \\
\hline < 1 juta & Buruk & 0.25 \\
\hline 2 Juta & Baik & 0.5 \\
\hline > 3 Juta & Sangat Baik & 1.0 \\
\hline
\end{tabular}

Berikut ini adalah alternatif berdasarkan kriteria pada perhitungan metode Moora

\begin{tabular}{|c|c|c|c|c|c|}
\hline Alternatif & C1 & C2 & C3 & C4 & C5 \\
\hline A1 & 1 & 0.25 & 0.5 & 0.25 & 0.5 \\
\hline A2 & 1 & 0.25 & 0.5 & 0.5 & 0.5 \\
\hline A3 & 1 & 1 & 0.5 & 1 & 1 \\
\hline A4 & 1 & 0.25 & 0.5 & 0.25 & 0.25 \\
\hline A5 & 1 & 0.25 & 0.25 & 0.25 & 0.25 \\
\hline A6 & 1 & 0.25 & 0.25 & 0.25 & 0.25 \\
\hline A7 & 1 & 0.5 & 1 & 0.5 & 0.5 \\
\hline A8 & 0.5 & 0.25 & 0.25 & 0.25 & 0.25 \\
\hline A9 & 1 & 0.25 & 0.5 & 0.5 & 0.25 \\
\hline A10 & 1 & 0.25 & 0.5 & 0.5 & 0.5 \\
\hline A11 & 1 & 0.25 & 0.25 & 0.25 & 0.25 \\
\hline A12 & 1 & 0.5 & 0.25 & 0.5 & 1 \\
\hline A13 & 1 & 0.5 & 1 & 1 & 0.5 \\
\hline A14 & 1 & 0.5 & 0.5 & 1 & 0.5 \\
\hline A15 & 1 & 1 & 1 & 1 & 0.5 \\
\hline A16 & 1 & 0.5 & 0.5 & 0.5 & 0.5 \\
\hline A17 & 1 & 0.25 & 0.25 & 0.25 & 0.25 \\
\hline A18 & 1 & 0.25 & 0.5 & 0.25 & 0.25 \\
\hline A19 & 1 & 1 & 1 & 1 & 0.5 \\
\hline A20 & 0.5 & 0.5 & 0.25 & 0.25 & 0.25 \\
\hline A21 & 1 & 0.25 & 0.25 & 0.5 & 0.25 \\
\hline
\end{tabular}

\begin{tabular}{|c|c|c|c|c|c|}
\hline Alternatif & C1 & C2 & C3 & C4 & C5 \\
\hline A1 & 1 & 0.25 & 0.5 & 0.25 & 2 Juta \\
\hline A2 & 1 & 0.25 & 0.5 & 0.5 & 1.5 Juta \\
\hline A3 & 1 & 1 & 0.5 & 1 & 5 Juta \\
\hline A4 & 1 & 0.25 & 0.5 & 0.25 & 1 Juta \\
\hline A5 & 1 & 0.25 & 0.25 & 0.25 & 1 Juta \\
\hline A6 & 1 & 0.25 & 0.25 & 0.25 & 1 Juta \\
\hline A7 & 1 & 0.5 & 1 & 0.5 & 2 Juta \\
\hline A8 & 0.5 & 0.25 & 0.25 & 0.25 & 1 Juta \\
\hline A9 & 1 & 0.25 & 0.5 & 0.5 & 1 Juta \\
\hline A10 & 1 & 0.25 & 0.5 & 0.5 & 1.7 Juta \\
\hline A11 & 1 & 0.25 & 0.25 & 0.25 & 1 Juta \\
\hline
\end{tabular}




\begin{tabular}{|c|c|c|c|c|c|}
\hline $\mathrm{A} 12$ & 1 & 0.5 & 0.25 & 0.5 & 3 Juta \\
\hline $\mathrm{A} 13$ & 1 & 0.5 & 1 & 1 & 2 Juta \\
\hline $\mathrm{A} 14$ & 1 & 0.5 & 0.5 & 1 & 2 Juta \\
\hline $\mathrm{A} 15$ & 1 & 1 & 1 & 1 & 2 Juta \\
\hline $\mathrm{A} 16$ & 1 & 0.5 & 0.5 & 0.5 & 2 Juta \\
\hline $\mathrm{A} 17$ & 1 & 0.25 & 0.25 & 0.25 & 800 Ribu \\
\hline $\mathrm{A} 18$ & 1 & 0.25 & 0.5 & 0.25 & 900 Ribu \\
\hline $\mathrm{A} 19$ & 1 & 1 & 1 & 1 & 2 Juta \\
\hline $\mathrm{A} 20$ & 0.5 & 0.5 & 0.25 & 0.25 & 500 Ribu \\
\hline $\mathrm{A} 21$ & 1 & 0.25 & 0.25 & 0.5 & 750 Ribu \\
\hline
\end{tabular}

Setelah didapatkan nilai nilai alternatif yang telah di bobotkan, maka dilakukan pemrosesan keputusan menggunakan metode MOORA :

1. Matrik Keputusan X

\begin{tabular}{|ccccc}
1 & 0.25 & 0.5 & 0.25 & 2 Juta \\
1 & 0.25 & 0.5 & 0.5 & 1.5 Juta \\
1 & 1 & 0.5 & 1 & 5 Juta \\
1 & 0.25 & 0.5 & 0.25 & 1 Juta \\
1 & 0.25 & 0.25 & 0.25 & 1 Juta \\
1 & 0.25 & 0.25 & 0.25 & 1 Juta \\
1 & 0.5 & 1 & 0.5 & 2 Juta \\
0.5 & 0.25 & 0.25 & 0.25 & 1 Juta \\
1 & 0.25 & 0.5 & 0.5 & 1 Juta \\
1 & 0.25 & 0.5 & 0.5 & 1.7 Juta \\
1 & 0.25 & 0.25 & 0.25 & 1 Juta \\
1 & 0.5 & 0.25 & 0.5 & 3 Juta \\
1 & 0.5 & 1 & 1 & 2 Juta \\
1 & 0.5 & 0.5 & 1 & 2 Juta \\
1 & 1 & 1 & 1 & 2 Juta \\
1 & 0.5 & 0.5 & 0.5 & 2 Juta \\
1 & 0.25 & 0.25 & 0.25 & 800 \\
& & & & Ribu \\
1 & 0.25 & 0.5 & 0.25 & R00 \\
1 & 1 & 1 & 1 & 2 Juta \\
0.5 & 0.5 & 0.25 & 0.25 & 500 \\
1 & 0.25 & 0.25 & 0.5 & Ribu \\
1 & & & & Ribu
\end{tabular}

2. Melakukan normalisasi matriks

$$
\begin{aligned}
& \mathrm{C} 1=\sqrt{1^{2}}+1^{2}+1^{2}+1^{2}+1^{2}+1^{2}+1^{2}+0.5^{2}+1^{2}+1^{2}+1^{2}+1^{2}+1^{2}+1^{2} \\
& =\sqrt{19.5}=4.42 \\
& +1^{2}+1^{2}+1^{2}+1^{2}+1^{2}+0.5^{2}+1^{2} \\
& \mathrm{~A} 1=1 / 4.42=0.23 \\
& \mathrm{~A} 2=1 / 4.42=0.23 \\
& \mathrm{~A} 3=1 / 4.42=0.23 \\
& \mathrm{~A} 4=1 / 4.42=0.23
\end{aligned}
$$


$\mathrm{A} 5=1 / 4.42=0.23$

$\mathrm{A} 6=1 / 4.42=0.23$

$\mathrm{A} 7=1 / 4.42=0.23$

$\mathrm{A} 8=0.5 / 4.42=0.11$

$\mathrm{A} 21=1 / 4.42=0.23$

\begin{tabular}{|c|c|c|c|c|c|c|c|c|c|c|c|c|c|c|c|c|c|c|c|c|c|}
\hline & A1 & A2 & A3 & A4 & A5 & A6 & A7 & A8 & A9 & A10 & A11 & A12 & A13 & A14 & A15 & A16 & A17 & A18 & A19 & A20 & A21 \\
\hline C1 & 0.23 & 0.23 & 0.23 & 0.23 & 0.23 & 0.23 & 0.23 & 0.11 & 0.23 & 0.23 & 0.23 & 0.23 & 0.23 & 0.23 & 0.23 & 0.23 & 0.23 & 0.23 & 0.23 & 0.11 & 0.23 \\
\hline
\end{tabular}

$$
\begin{aligned}
\mathrm{C} 2=\sqrt{0.25^{2}}+ & 0.25^{2}+1^{2}+0.25^{2}+0.25^{2}+0.25^{2}+0.5^{2}+0.25^{2}+0.25^{2}+0.25^{2} \\
& +0.25^{2}+0.5^{2}+0.5^{2}+0.5^{2}+1^{2}+0.5^{2}+0.25^{2}+0.25^{2}+1^{2} \\
& +0.5^{2}+0.25^{2}
\end{aligned}
$$

$=\sqrt{0.06}+0.06+1+0.06+0.06+0.06+0.25+0.06+0.06+0.06+0.06+$

$0.25+0.25+0.25+1+0.25+0.06+0.06+1+0.25+0.06=\sqrt{5.22}=2.28$

$\mathrm{A} 1=0.25 / 2.28=0.11$

$\mathrm{A} 2=0.25 / 2.28=0.11$

$\mathrm{A} 3=1 / 2.28=0.44$

$\mathrm{A} 7=0.5 / 2.28=0.22$

$\mathrm{A} 21=0.25 / 2.28=0.11$

\begin{tabular}{|c|c|c|c|c|c|c|c|c|c|c|c|c|c|c|c|c|c|c|c|c|c|}
\hline & A1 & A2 & A3 & A4 & A5 & A6 & A7 & A8 & A9 & A10 & A11 & A12 & A13 & A14 & A15 & A16 & A17 & A18 & A19 & A20 & A21 \\
\hline C2 & 0.11 & 0.11 & 0.44 & 0.11 & 0.11 & 0.11 & 0.22 & 0.11 & 0.11 & 0.11 & 0.11 & 0.22 & 0.22 & 0.22 & 0.44 & 0.22 & 0.11 & 0.11 & 0.44 & 0.22 & 0.11 \\
\hline
\end{tabular}

$$
\begin{gathered}
\mathrm{C} 3=\sqrt{0.5^{2}}+0.5^{2}+0.5^{2}+0.5^{2}+0.25^{2}+0.25^{2}+1^{2}+0.25^{2}+0.5^{2}+0.5^{2}+0.25^{2} \\
+0.25^{2}+1^{2}+0.5^{2}+1^{2}+0.5^{2}+0.25^{2}+0.25^{2}+1^{2}+0.25^{2}+0.25^{2} \\
=\sqrt{0.25}+0.25+0.25+0.25+0.06+0.06+1+0.06+0.25+0.25+0.06+0.06+1 \\
+0.25+1+0.25+0.06+0.06+1+0.06+0.06=\sqrt{7.54}=2.75
\end{gathered}
$$

$\mathrm{A} 1=0.5 / 2.75=0.18$

$\mathrm{A} 2=0.5 / 2.75=0.18$

$\mathrm{A} 3=0.5 / 2.75=0.18$

$\mathrm{A} 4=0.5 / 2.75=0.18$

$\mathrm{A} 5=0.25 / 2.75=0.09$

$\mathrm{A} 6=0.25 / 2.75=0.09$

$\mathrm{A} 7=1 / 2.75=0.36$

$\mathrm{A} 21=0.25 / 2.75=0.09$

\begin{tabular}{|c|c|c|c|c|c|c|c|c|c|c|c|c|c|c|c|c|c|c|c|c|c|}
\hline & A1 & A2 & A3 & A4 & A5 & A6 & A7 & A8 & A9 & A10 & A11 & A12 & A13 & A14 & A15 & A16 & A17 & A18 & A19 & A20 & A21 \\
\hline C3 & 0.18 & 0.18 & 0.18 & 0.18 & 0.09 & 0.09 & 0.36 & 0.09 & 0.18 & 0.18 & 0.09 & 0.09 & 0.36 & 0.18 & 0.36 & 0.18 & 0.09 & 0.09 & 0.36 & 0.09 & 0.09 \\
\hline
\end{tabular}

$$
\begin{aligned}
\mathrm{C} 4=\sqrt{0.25^{2}}+ & 0.5^{2}+1^{2}+0.25^{2}+0.25^{2}+0.25^{2}+0.5^{2}+0.25^{2}+0.5^{2}+0.5^{2} \\
+ & 0.25^{2}+0.5^{2}+1^{2}+1^{2}+1^{2}+0.5^{2}+0.25^{2}+0.25^{2}+1^{2}+0.25^{2} \\
+ & 0.5^{2} \\
=\sqrt{0.06}+ & 0.25+1+0.06+0.06+0.06+0.25+0.06+0.25+0.25+0.06 \\
+ & 0.25+1+1+1+0.25+0.06+0.06+1+0.06+0.25 \\
= & \sqrt{7.29}=2.7
\end{aligned}
$$

$\mathrm{A} 1=0.25 / 2.7=0.10$

$\mathrm{A} 2=0.5 / 2.7=0.19$

$\mathrm{A} 3=1 / 2.7=0.37$ 
$\mathrm{A} 4=0.25 / 2.7=0.10$

$\mathrm{A} 21=0.5 / 2.7=0.19$

\begin{tabular}{|c|c|c|c|c|c|c|c|c|c|c|c|c|c|c|c|c|c|c|c|c|c|}
\hline & A1 & A2 & A3 & A4 & A5 & A6 & A7 & A8 & A9 & A10 & A11 & A12 & A13 & A14 & A15 & A16 & A17 & A18 & A19 & A20 & A21 \\
\hline C4 & 0.10 & 0.19 & 0.37 & 0.10 & 0.10 & 0.10 & 0.19 & 0.10 & 0.19 & 0.19 & 0.10 & 0.19 & 0.37 & 0.37 & 0.37 & 0.19 & 0.10 & 0.10 & 0.37 & 0.19 & 0.19 \\
\hline
\end{tabular}

$$
\begin{aligned}
\mathrm{C} 5=\sqrt{200000} & +1500000+5000000+1000000+1000000+1000000 \\
& +2000000+1000000+1000000+1700000+1000000 \\
& +3000000+2000000+2000000+2000000+2000000 \\
& +800000+900000+2000000+500000+750000 \\
=\sqrt{4 \mathrm{~T}}+2.25 \mathrm{~T}+ & 25 \mathrm{~T}+1 \mathrm{~T}+1 \mathrm{~T}+1 \mathrm{~T}+4 \mathrm{~T}+1 \mathrm{~T}+1 \mathrm{~T}+2.89 \mathrm{~T}+1 \mathrm{~T}+9 \mathrm{~T}+4 \mathrm{~T} \\
+ & 4 \mathrm{~T}+4 \mathrm{~T}+4 \mathrm{~T}+640 \mathrm{M}+810 \mathrm{M}+4 \mathrm{~T}+250 \mathrm{M}+562.5 \mathrm{M} \\
= & \sqrt{7.316 .262 .500 .000 .000}=85.535 .153 .592
\end{aligned}
$$

\begin{tabular}{|c|c|c|c|c|c|c|c|c|c|c|c|c|c|c|c|c|c|c|c|c|c|}
\hline & A1 & A2 & A3 & A4 & A5 & A6 & A7 & A8 & A9 & $\mathrm{A} 10$ & A11 & $\mathrm{A} 12$ & $\mathrm{~A} 13$ & A14 & A15 & A16 & A17 & A18 & A19 & $\mathrm{A} 20$ & A 21 \\
\hline C5 & 0.023 & 0.017 & 0.058 & 0.012 & 0.012 & 0.012 & 0.023 & 0.012 & 0.012 & 0.020 & 0.012 & 0.035 & 0.023 & 0.023 & 0.023 & 0.023 & 0.009 & 0.011 & 0.023 & 0.005 & 0.009 \\
\hline
\end{tabular}

$\mathrm{A} 1=2.000 .000 / 85.535 .153 .592=0.023$

$\mathrm{A} 2=1.500 .000 / 85.535 .153 .592=0.017$

$\mathrm{A} 3=5.000 .000 / 85.535 .153 .592=0.058$

$\mathrm{A} 4=1.000 .000 / 85.535 .153 .592=0.012$

$\mathrm{A} 21=750.000 / 85.535 .153 .592=0.009$

3. Hasilnya dari Nirmalisasi Matriks $X$ diperoleh matriks $X * i j$ dilihat berikut ini.

$\mathrm{X}=\mid$\begin{tabular}{lllll|}
0.23 & 0.11 & 0.18 & 0.10 & 0.023 \\
0.23 & 0.11 & 0.18 & 0.19 & 0.017 \\
0.23 & 0.44 & 0.18 & 0.37 & 0.058 \\
0.23 & 0.11 & 0.18 & 0.10 & 0.012 \\
0.23 & 0.11 & 0.09 & 0.10 & 0.012 \\
0.23 & 0.11 & 0.09 & 0.10 & 0.012 \\
0.23 & 0.22 & 0.36 & 0.19 & 0.023 \\
0.11 & 0.11 & 0.09 & 0.10 & 0.012 \\
0.23 & 0.11 & 0.18 & 0.19 & 0.012 \\
0.23 & 0.11 & 0.18 & 0.19 & 0.020 \\
0.23 & 0.11 & 0.09 & 0.10 & 0.012 \\
0.23 & 0.22 & 0.09 & 0.19 & 0.035 \\
0.23 & 0.22 & 0.36 & 0.37 & 0.023 \\
0.23 & 0.22 & 0.18 & 0.37 & 0.023 \\
0.23 & 0.44 & 0.36 & 0.37 & 0.023 \\
0.23 & 0.22 & 0.18 & 0.19 & 0.023 \\
0.23 & 0.11 & 0.09 & 0.10 & 0.009 \\
0.23 & 0.11 & 0.09 & 0.10 & 0.011 \\
0.23 & 0.44 & 0.36 & 0.37 & 0.023 \\
0.11 & 0.22 & 0.09 & 0.19 & 0.005 \\
0.23 & 0.11 & 0.09 & 0.19 & 0.009
\end{tabular}

Mengoptimalkan atribut Menyertakan bobot dalam pencarian yang ternormalisasi
$0.23(0.25)$
0.11
$0.18(0.20)$
$0.10(0.15)$
$0.23(0.25)$
(0.20)
0.11
(0.20)
$0.18(0.20)$
$0.19(0.15)$

$0.023(0.20)$

$0.017(0.20)$ 


\begin{tabular}{|c|c|c|c|c|c|}
\hline \multirow{19}{*}{$X=$} & $0.23(0.25)$ & $\begin{array}{l}0.44 \\
(0.20)\end{array}$ & $0.18(0.20)$ & $0.37(0.15)$ & $0.058(0.20)$ \\
\hline & $0.23(0.25)$ & $\begin{array}{l}0.11 \\
(0.20)\end{array}$ & $0.18(0.20)$ & $0.10(0.15)$ & $0.012(0.20)$ \\
\hline & $0.23(0.25)$ & $\begin{array}{l}0.11 \\
(0.20)\end{array}$ & $0.09(0.20)$ & $0.10(0.15)$ & $0.012(0.20)$ \\
\hline & $0.23(0.25)$ & $\begin{array}{l}0.11 \\
(0.20)\end{array}$ & $0.09(0.20)$ & $0.10(0.15)$ & $0.012(0.20)$ \\
\hline & $0.23(0.25)$ & $\begin{array}{l}0.22 \\
(0.20)\end{array}$ & $0.36(0.20)$ & $0.19(0.15)$ & $0.023(0.20)$ \\
\hline & $0.11(0.25)$ & $\begin{array}{l}0.11 \\
(0.20)\end{array}$ & $0.09(0.20)$ & $0.10(0.15)$ & $0.012(0.20)$ \\
\hline & $0.23(0.25)$ & $\begin{array}{l}0.11 \\
(0.20)\end{array}$ & $0.18(0.20)$ & $0.19(0.15)$ & $0.012(0.20)$ \\
\hline & $0.23(0.25)$ & $\begin{array}{l}0.11 \\
(0.20)\end{array}$ & $0.18(0.20)$ & $0.19(0.15)$ & $0.020(0.20)$ \\
\hline & $0.23(0.25)$ & $\begin{array}{l}0.11 \\
(0.20)\end{array}$ & $0.09(0.20)$ & $0.10(0.15)$ & $0.012(0.20)$ \\
\hline & $0.23(0.25)$ & $\begin{array}{l}0.22 \\
(0.20)\end{array}$ & $0.09(0.20)$ & $0.19(0.15)$ & $0.035(0.20)$ \\
\hline & $0.23(0.25)$ & $\begin{array}{l}0.22 \\
(0.20)\end{array}$ & $0.36(0.20)$ & $0.37(0.15)$ & $0.023(0.20)$ \\
\hline & $0.23(0.25)$ & $\begin{array}{l}0.22 \\
(0.20)\end{array}$ & $0.18(0.20)$ & $0.37(0.15)$ & $0.023(0.20)$ \\
\hline & $0.23(0.25)$ & $\begin{array}{l}0.44 \\
(0.20)\end{array}$ & $0.36(0.20)$ & $0.37(0.15)$ & $0.023(0.20)$ \\
\hline & $0.23(0.25)$ & $\begin{array}{l}0.22 \\
(0.20)\end{array}$ & $0.18(0.20)$ & $0.19(0.15)$ & $0.023(0.20)$ \\
\hline & $0.23(0.25)$ & $\begin{array}{l}0.11 \\
(0.20)\end{array}$ & $0.09(0.20)$ & $0.10(0.15)$ & $0.009(0.20)$ \\
\hline & $0.23(0.25)$ & $\begin{array}{l}0.11 \\
(0.20)\end{array}$ & $0.09(0.20)$ & $0.10(0.15)$ & $0.011(0.20)$ \\
\hline & $0.23(0.25)$ & $\begin{array}{l}0.44 \\
(0.20)\end{array}$ & $0.36(0.20)$ & $0.37(0.15)$ & $0.023(0.20)$ \\
\hline & $0.11(0.25)$ & $\begin{array}{l}0.22 \\
(0.20)\end{array}$ & $0.09(0.20)$ & $0.19(0.15)$ & $0.005(0.20)$ \\
\hline & $0.23(0.25)$ & $\begin{array}{l}0.11 \\
(0.20)\end{array}$ & $0.09(0.20)$ & $0.19(0.15)$ & $0.009(0.20)$ \\
\hline
\end{tabular}

Hasil perkalian dengan bobot kriteria, yaitu:

$\mathrm{X}=\left|\begin{array}{ccccc}0.0575 & 0.0220 & 0.0360 & 0.0150 & 0.0046 \\ 0.0575 & 0.0220 & 0.0360 & 0.0285 & 0.0034 \\ 0.0575 & 0.0880 & 0.0360 & 0.0555 & 0.0116 \\ 0.0575 & 0.0220 & 0.0360 & 0.0150 & 0.0024 \\ 0.0575 & 0.0220 & 0.0180 & 0.0150 & 0.0024 \\ 0.0575 & 0.0220 & 0.0180 & 0.0150 & 0.0024 \\ 0.0575 & 0.0440 & 0.0720 & 0.0285 & 0.0046 \\ 0.0275 & 0.0220 & 0.0180 & 0.0150 & 0.0024 \\ 0.0575 & 0.0220 & 0.0360 & 0.0285 & 0.0024 \\ 0.0575 & 0.0220 & 0.0360 & 0.0285 & 0.0040 \\ 0.0575 & 0.0220 & 0.0180 & 0.0150 & 0.0024 \\ 0.0575 & 0.0440 & 0.0180 & 0.0285 & 0.0070\end{array}\right|$




\begin{tabular}{lllll|}
0.0575 & 0.0440 & 0.0720 & 0.0555 & 0.0046 \\
0.0575 & 0.0440 & 0.0360 & 0.0555 & 0.0046 \\
0.0575 & 0.0880 & 0.0720 & 0.0555 & 0.0046 \\
0.0575 & 0.0440 & 0.0360 & 0.0285 & 0.0046 \\
0.0575 & 0.0220 & 0.0180 & 0.0150 & 0.0018 \\
0.0575 & 0.0220 & 0.0180 & 0.0150 & 0.0022 \\
0.0575 & 0.0880 & 0.0720 & 0.0555 & 0.0046 \\
0.0275 & 0.0440 & 0.0180 & 0.0285 & 0.0010 \\
0.0575 & 0.0220 & 0.0180 & 0.0285 & 0.0018
\end{tabular}

4. Menentukan Hasil Preferensi

Hasil referensinya (Yi) seperti pada tabel dibawah ini

\begin{tabular}{|c|c|c|c|}
\hline Alternatif & $\begin{array}{l}\text { Max } \\
(\mathrm{C} 1+\mathrm{C} 2+\mathrm{C} 3)\end{array}$ & $\begin{array}{l}\text { Min } \\
(\mathrm{C} 4+\mathrm{C} 5)\end{array}$ & $\begin{array}{l}\text { Yi }=\text { Max - } \\
\text { Min }\end{array}$ \\
\hline $\mathrm{A} 1$ & 0.1155 & 0.0196 & 0.0959 \\
\hline $\mathrm{A} 2$ & 0.1155 & 0.0319 & 0.0836 \\
\hline $\mathrm{A} 3$ & 0.1815 & 0.0671 & 0.1144 \\
\hline $\mathrm{A} 4$ & 0.1155 & 0.0174 & 0.0981 \\
\hline $\mathrm{A} 5$ & 0.0975 & 0.0174 & 0.0801 \\
\hline $\mathrm{A} 6$ & 0.0975 & 0.0174 & 0.0801 \\
\hline $\mathrm{A} 7$ & 0.1735 & 0.0331 & 0.1404 \\
\hline $\mathrm{A} 8$ & 0.0675 & 0.0174 & 0.0501 \\
\hline $\mathrm{A} 9$ & 0.1155 & 0.0309 & 0.0846 \\
\hline $\mathrm{A} 10$ & 0.1155 & 0.0325 & 0.083 \\
\hline $\mathrm{A} 11$ & 0.0975 & 0.0174 & 0.0801 \\
\hline $\mathrm{A} 12$ & 0.1195 & 0.0355 & 0.084 \\
\hline $\mathrm{A} 13$ & 0.1735 & 0.0601 & 0.1134 \\
\hline $\mathrm{A} 14$ & 0.1375 & 0.0601 & 0.0774 \\
\hline $\mathrm{A} 15$ & 0.2175 & 0.0601 & 0.1574 \\
\hline $\mathrm{A} 16$ & 0.1375 & 0.0331 & 0.1044 \\
\hline $\mathrm{A} 17$ & 0.0975 & 0.0168 & 0.0807 \\
\hline $\mathrm{A} 18$ & 0.0975 & 0.0172 & 0.0803 \\
\hline A19 & 0.2175 & 0.0601 & 0.1574 \\
\hline A20 & 0.0895 & 0.0295 & 0.06 \\
\hline A21 & 0.0975 & 0.0303 & 0.0672 \\
\hline & & & \\
\hline
\end{tabular}

Dari hasil diatas, dapat dilihat rangking setiap alternatif dari Badan Usaha Milik Desa (BumDes) di Kabupaten Kampar dengan menggunakan metode Moora adalah

\begin{tabular}{|c|c|c|}
\hline Alternatif & $\begin{array}{c}\text { Yi }=\text { Max - } \\
\text { Min }\end{array}$ & Rangking \\
\hline A15 & 0.1574 & 1 \\
\hline A19 & 0.1574 & 2 \\
\hline A7 & 0.1404 & 3 \\
\hline A3 & 0.1144 & 4 \\
\hline A13 & 0.1134 & 5 \\
\hline
\end{tabular}




\begin{tabular}{|c|c|c|} 
A16 & 0.1044 & 6 \\
\hline A4 & 0.0981 & 7 \\
\hline A1 & 0.0959 & 8 \\
\hline A9 & 0.0846 & 9 \\
\hline A12 & 0.084 & 10 \\
\hline
\end{tabular}

Peneliti juga sedang melakukan pengujian web SPK yang telah selesai dirancang. Berikut ini adalah tampilan web SPK yang sudah dibangun.

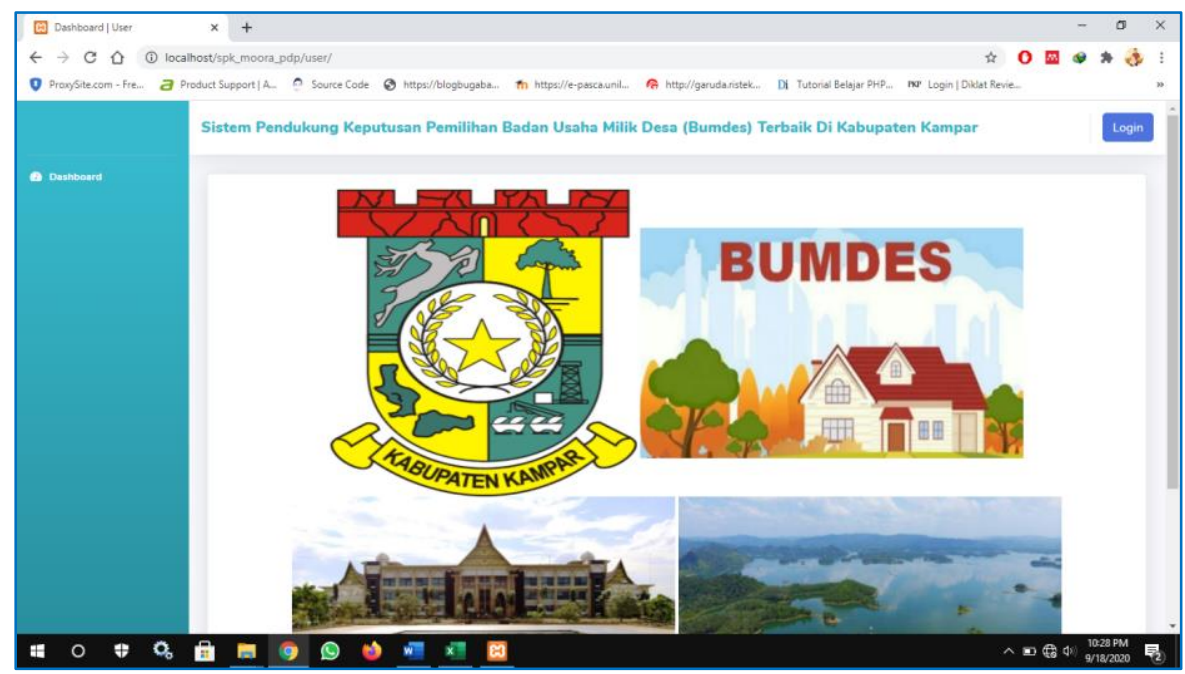

Gambar 2. Tampilan Web SPK Metode Moora

Pada proses metode Moora maka di dapat antar muka website SPK sebagai berikut adalah data BumDes yang ada di Kabupaten Kampar direkap didalam sistem.

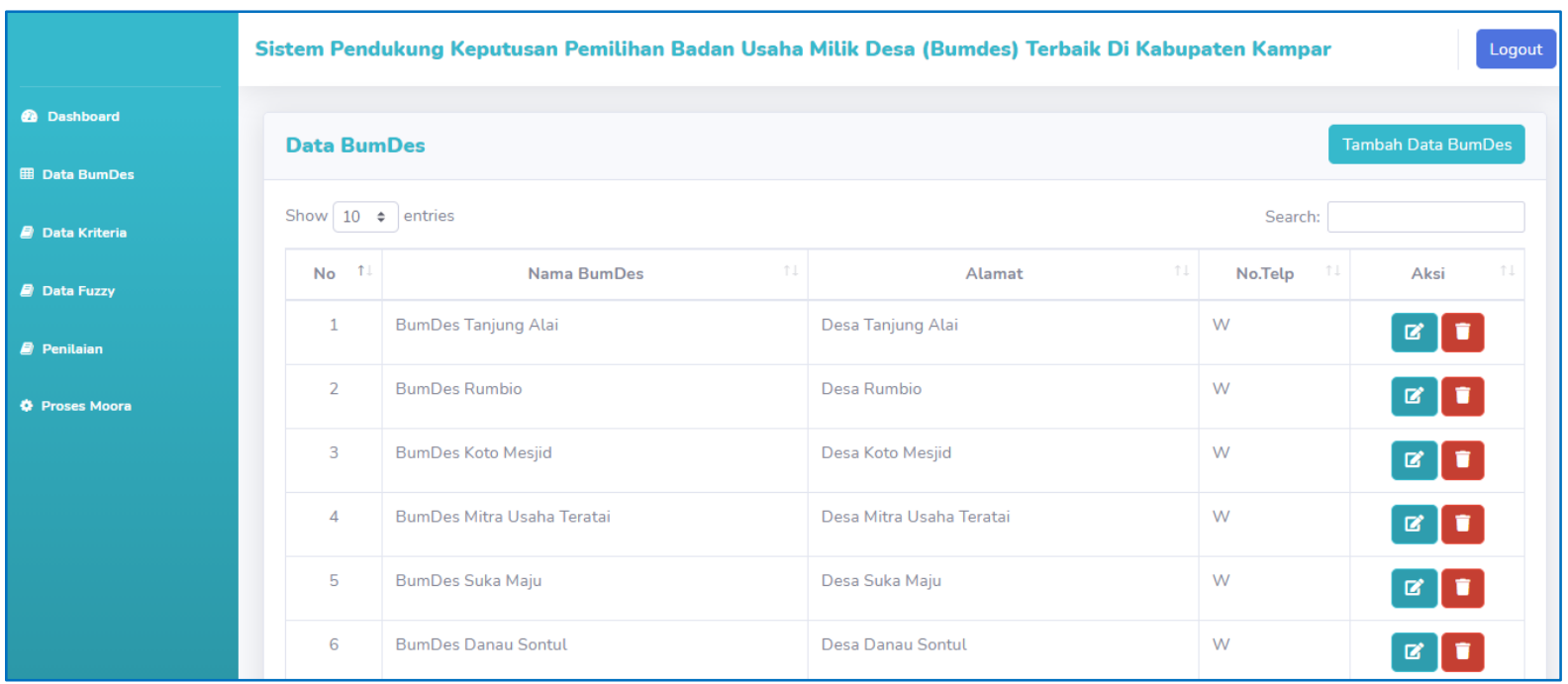

Gambar 3. Data BumDes kabupaten Kampar 
Dalam perhitungan Metode Moora selanjutnya adalah menentukan kriteria yang digunakan seperti pada gambar berikut ini

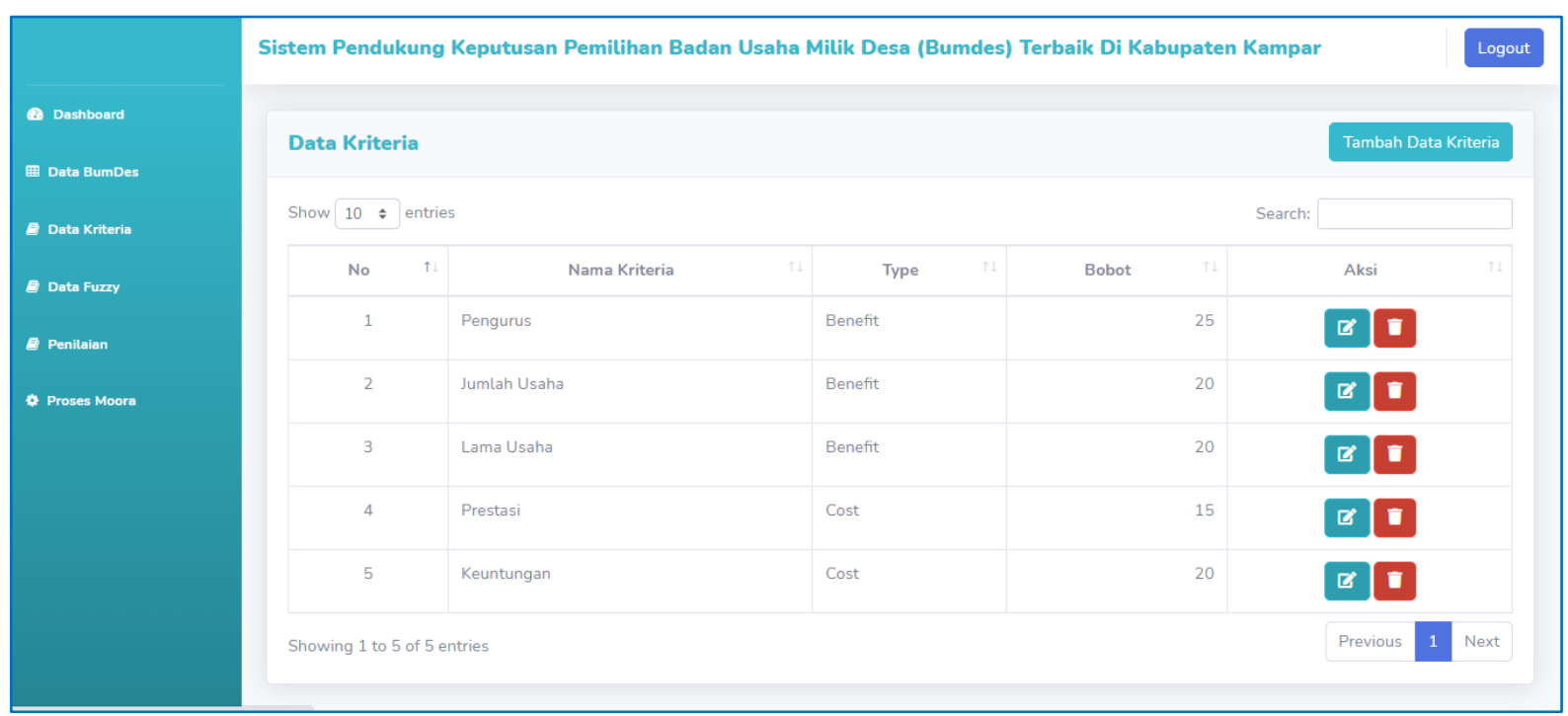

Gambar 4. Data Kriteria

Selanjutnya adalah tahapan perhitungan data Fuzzy pada Metode Moora seperi pada gambar dibawah ini :

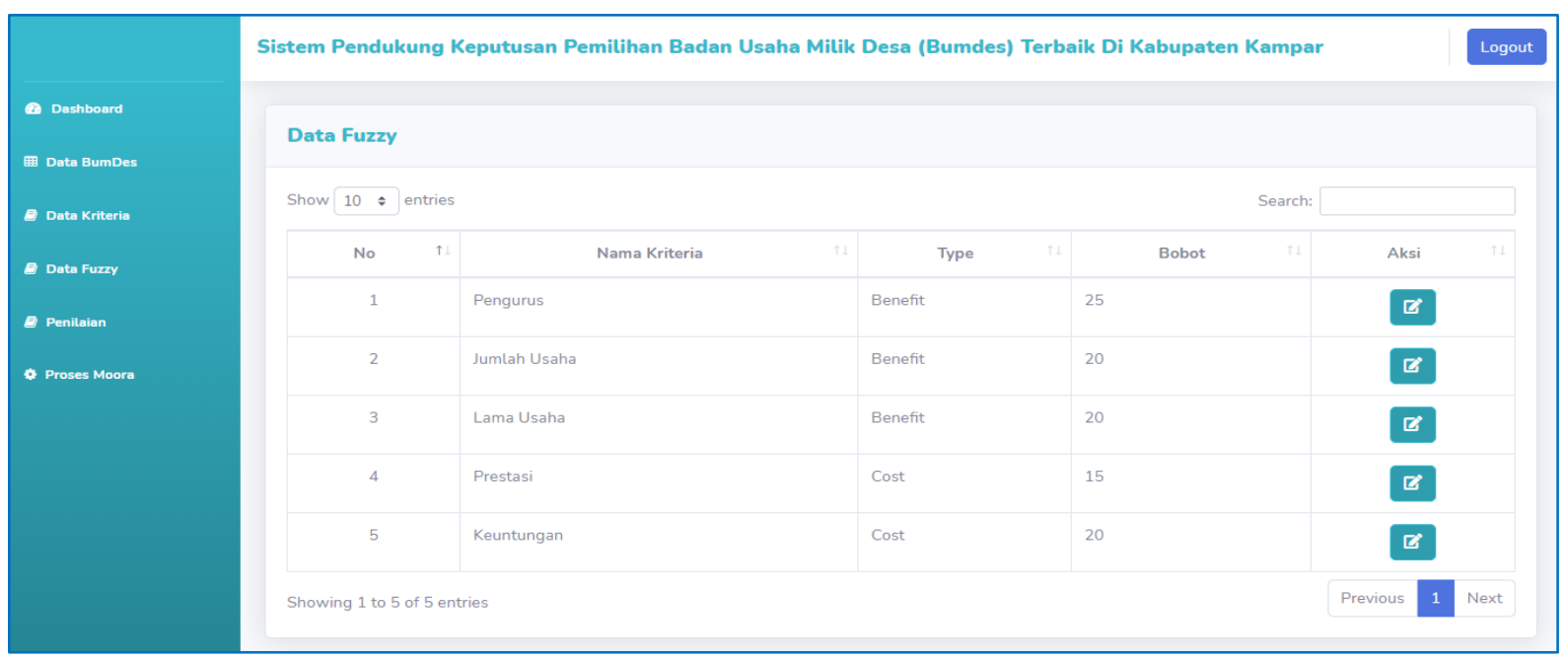

Gambar 5. Data Fuzzy 
Selanjutnya adalah proses memberikan penilaian bobotalternatif berdasarkan krtiteria penilaian

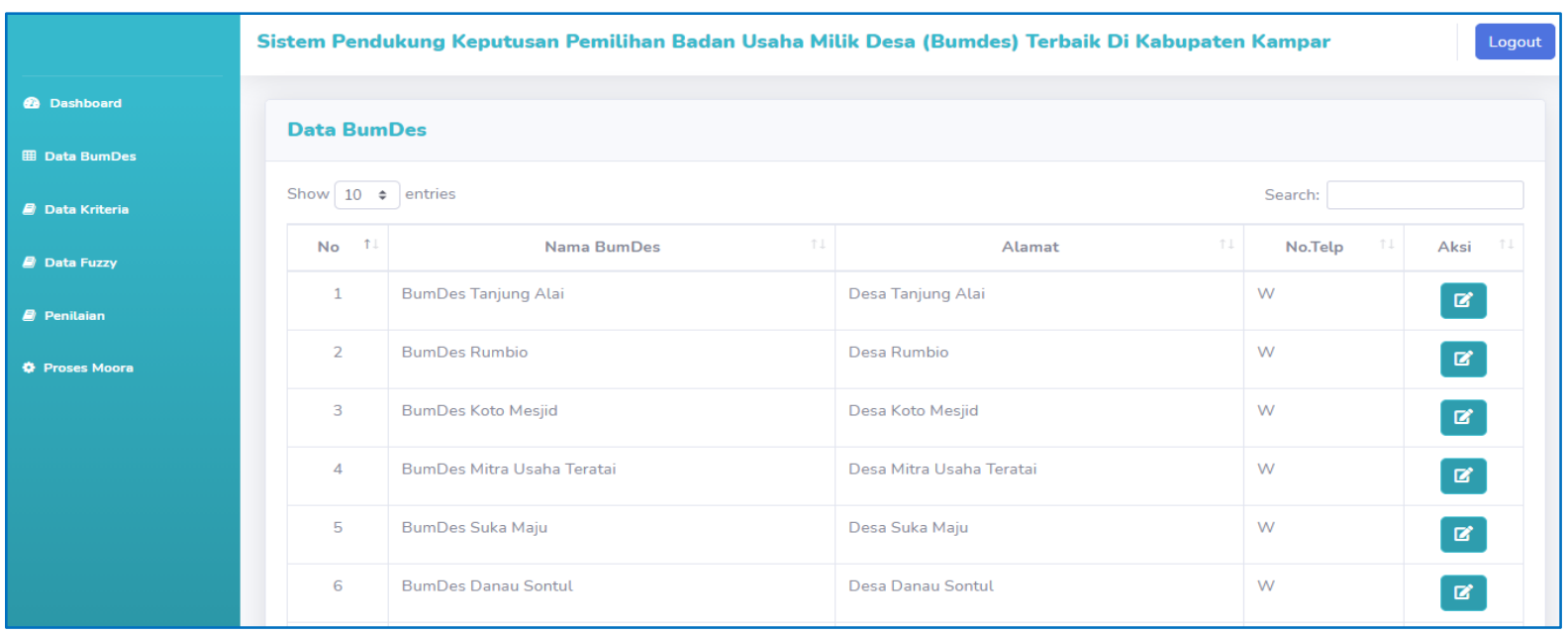

Gambar 6. List Penilaian Alternatif Berdasarkan Kriteria

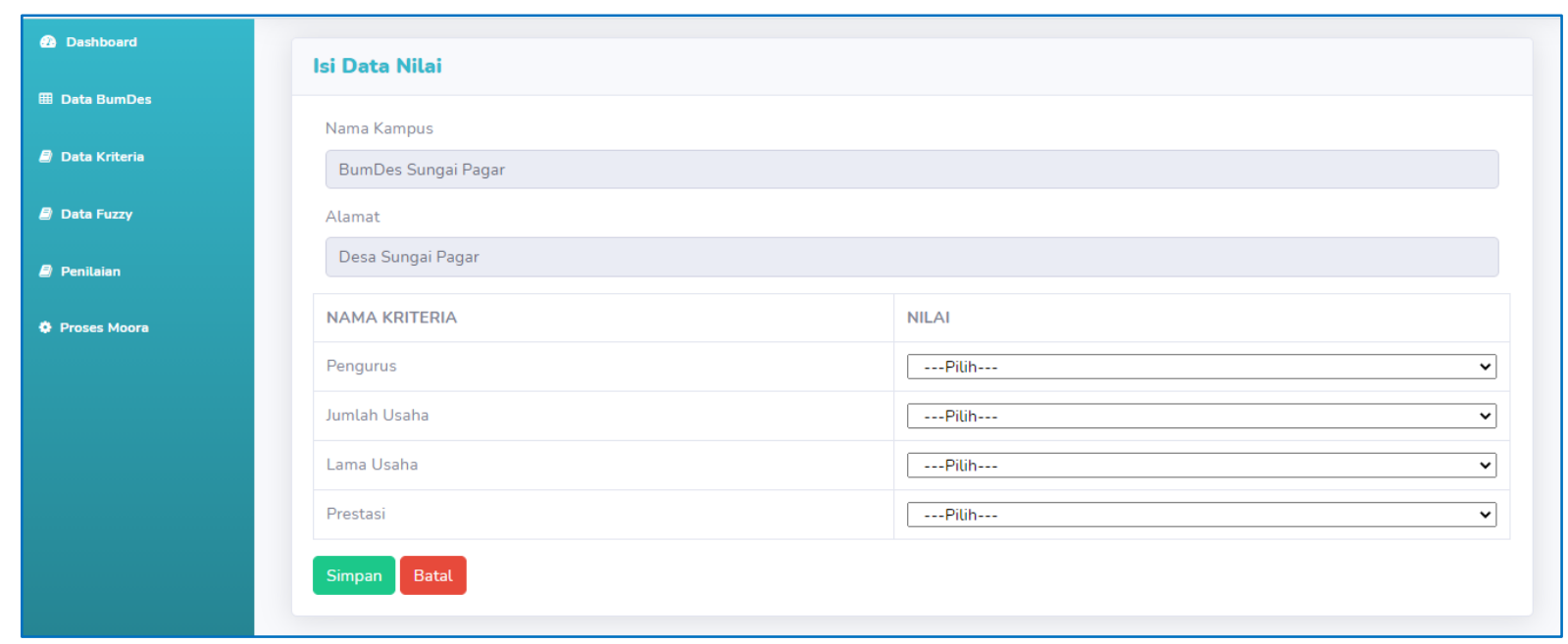

Gambar 7. List Penilaian Alternatif Berdasarkan Kriteria

Tahap akhir ini adalah penilaian yang dilakukan kepada Bumdes berdasarkan kriteria. Hasil ini sudah dijelaskan pada proses pencarian Sistem Penunjang Keputusan Metode Moora pada penjelesan sebelumnya seperti tergabar berikut 


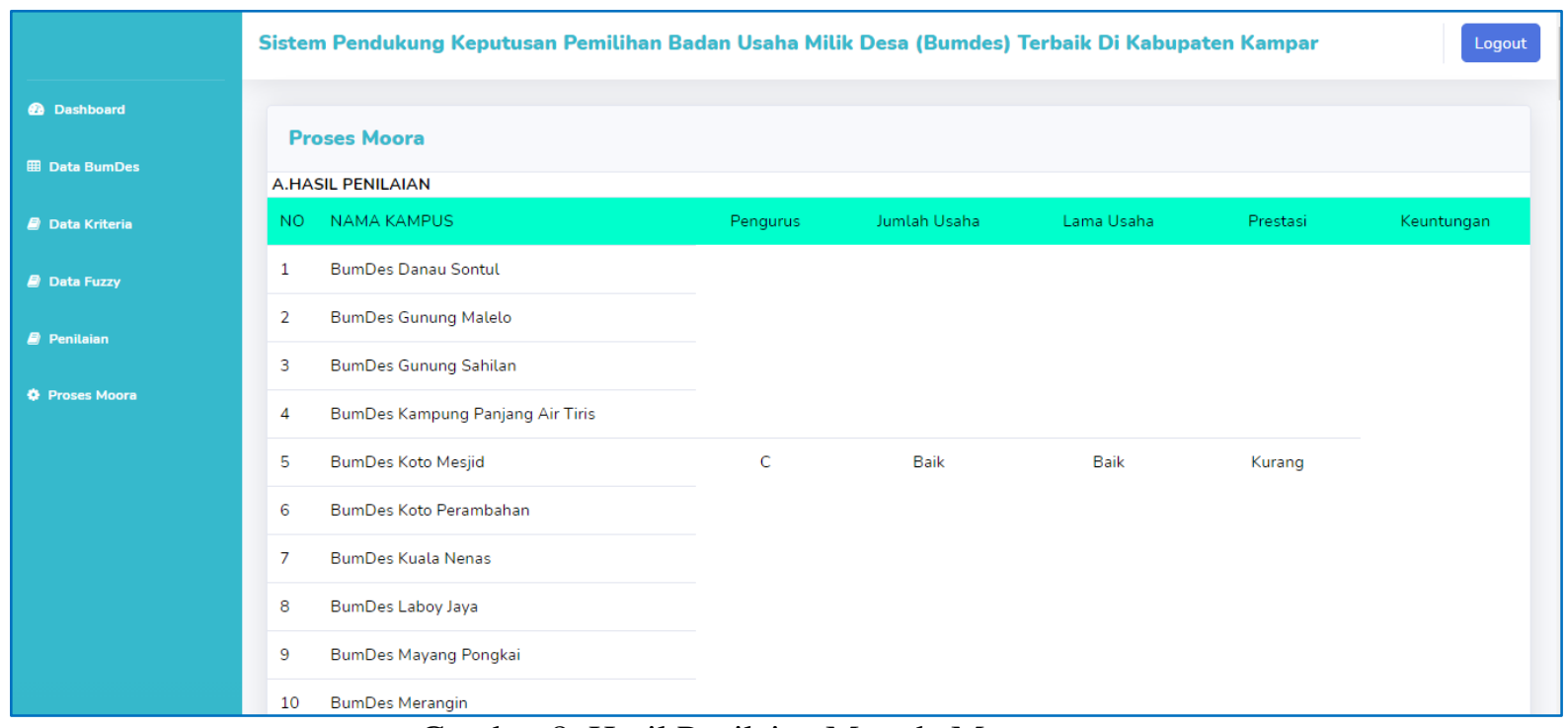

Gambar 8. Hasil Penilaian Metode Moora

\section{Kesimpulan}

Kesimpulan dari penelitian yang berjudul "Sistem Penunjang Keputusan Pemilihan BumDes Terbaik" dimana pada penelitian ini menggunakan metode Multi-Objective Optimization on the basis of Ratio Analysis (MOORA) adalah

a. Penelitian ini menggunakan sampel 21 BumDes di Kabupaten Kampar

b. Dari hasil penilai didapat hasil penilaian 10 BumDes terbaik dengan menggunakan metode Moora

c. Dari hasil didapatkan bahwanya BumDes dengan kriteria memiliki banyak jenis usaha dan keuntungan dan structural yang bagus menjadi BumDes terbaik yaitu Bumdes Kuala Nenas

\section{Daftar Pustaka}

[1] C. Irwana, Z. F. Harahap, And A. P. Windarto, "Spk: Analisa Metode Moora Pada Warga Penerima Bantuan Renovasi Rumah,” J. Teknol. Inf. Mura, 2018, Doi: 10.32767/Jti.V10i1.290.

[2] M. Mesran, S. D. A. Pardede, A. Harahap, And A. P. U. Siahaan, "Sistem Pendukung Keputusan Pemilihan Peserta Jaminan Kesehatan Masyarakat (Jamkesmas) Menerapkan Metode Moora," J. Media Inform. Budidarma, Vol. 2, No. 2, Pp. 16-22, 2018, Doi: 10.30865/Mib.V2i2.595.

[3] S. Rokhman, I. F. Rozi, And R. A. Asmara, "Pengembangan Sistem Penunjang Keputusan Penentuan Ukt Mahasiswa Dengan Menggunakan Metode Moora Studi Kasus Politeknik Negeri Malang," J. Inform. Polinema, Vol. 3, No. 4, P. 36, 2017, Doi: 10.33795/Jip.V3i4.41.

[4] M. A. Fadlun, K. Arivanty, H. W. S, And R. Amalia, "Sistem Pendukung Keputusan Untuk Menentukan Penerima Beasiswa Bank Bri Menggunakan Fmadm (Studi Kasus: Mahasiswa Fakultas Teknologi Industri Universitas Islam Indonesia)," Semin. Nas. Apl. Teknol. Inf., Vol. 2009, No. Snati, Pp. 62-67, 2009.

[5] F. Huda, K. Anuar, S. Syafri, And A. Susilawati, "Pembuatan Peta Geospasial Melalui Pemetaan Udara Pada Kelurahan Batu Bersurat, Kecamatan Xiii Koto Kampar, Kabupaten Kampar, Provinsi Riau," Din. J. Pengabdi. Kpd. Masy., Vol. 3, No. 1, Pp. 76-83, 2019, Doi: 10.31849/Dinamisia.V3i1.2060.

[6] R. Muliana, P. Astuti, And A. Fadli, "Kajian Pusat-Pusat Pelayanan Di Kabupaten Kampar," J. Saintis, Vol. 18, No. 1, Pp. 59-72, 2018, Doi: 
10.25299/Saintis.2018.Vol18(1).2846.

[7] S. Manurung, "Sistem Pendukung Keputusan Pemilihan Guru Dan Pegawai Terbaik Menggunakan Metode Moora," Simetris J. Tek. Mesin, Elektro Dan Ilmu Komput., Vol. 9, No. 1, Pp. 701-706, 2018, Doi: 10.24176/Simet.V9i1.1967.

[8] Apriyansyah, I. Maullidina, And E. P. Purnomo, "Efektivitas Sistem Informasi Desa (Sid) Dalam Pelayanan Publik Di Desa Dlingo, Kecamatan Dlingo, Kabupaten Bantul," J. Anal. Kebijak. Dan Pelayanan Publik, Vol. 4, No. 1, Pp. 10-24, 2018, [Online]. Available: Journal.Unhas.Ac.Id/Index.Php/Jakpp.

[9] A. Z. Siregar, P. Poningsih, And M. Safii, "Penentuan Kelayakan Penerimaan Bantuan Raskin Dengan Metode Moora Pada Kelurahan Martoba Pematangsiantar," Komik (Konferensi Nas. Teknol. Inf. Dan Komputer), Vol. 2, No. 1, 2018, Doi: 10.30865/Komik.V2i1.937.

[10] R. F. Sinaga, S. R. Andani, And S. Suhada, "Penentuan Penerima Kip Dengan Menggunakan Metode Moora Pada Sd Negeri 124395 Pematang Siantar," Komik (Konferensi Nas. Teknol. Inf. Dan Komputer), 2018, Doi: 10.30865/Komik.V2i1.938. 